\title{
Elastic Band Training Effect to Parameters of Sarcopenia in Elderly Community-Dwelling
}

\author{
Vitriana Biben, Irma Ruslina Defi, Derry Suselo \\ Department of Physical Medicine and Rehabilitation, Faculty of Medicine, \\ Universitas Padjadjaran/Dr. Hasan Sadikin Hospital, Bandung, Indonesia
}

\begin{abstract}
Physiologically aging causes the decreased of muscle mass, strength, and or limited activity known as sarcopenia in the elderly. The decrease in muscle capacity occurs in all elderly, active, or sedentary. Exercise for the elderly is considered not enough to prevent the decrease of function that will occur. Therefore, it is necessary to add strength training to the elderly, such as elastic band exercise. The effect of strength training in 12 weeks with elastic band strengthening exercise on muscle mass, muscle strength, and physical performance as sarcopenia parameters measured in this study. The interventional study design was conducted in elderly community-dwelling in Bandung city, West Java, from May to July 2016. Thirty elderly (60-81 years old) muscle mass measured using bioelectrical impedance analysis (BIA), handgrip strength using hand dynamometer and walking distance as the parameter of physical performance, using 6-minute walking test. Significant differences found in hand muscle strength $(\mathrm{p}=0.007)$, walking distance $(\mathrm{p}=0.000)$ after elastic band strengthening exercise, but there were no significant changes in muscle mass $(\mathrm{p}=0.236)$ even though the muscle mass increased after 12 weeks of strengthening exercise. In conclusion, additional elastic band strength exercise for regular elderly exercise can increase muscle strength and physical performance.
\end{abstract}

Key words: E lastic band, elderly, strengthening exercise

\section{Pengaruh Latihan dengan Pita Elastik terhadap Parameter Sarkopenia pada Usia Lanjut di Komunitas}

\begin{abstract}
Abstrak
Penuaan secara fisiologis menyebabkan penurunan massa, kekuatan otot dan/atau keterbatasan aktivitas pada usia lanjut (usila). Penurunan kemampuan otot ini terjadi pada semua usila, baik yang aktif maupun nonaktif sehingga senam usila yang ada dianggap tidak mencukupi untuk mencegah penurunan fungsi yang akan terjadi. Oleh karena itu, diperlukan penambahan latihan kekuatan pada usila seperti latihan kekuatan menggunakan pita elastik. Penelitian ini bertujuan mengetahui pengaruh latihan kekuatan dengan pita elastik selama 12 minggu terhadap massa otot, kekuatan otot, dan performa fisik yang merupakan parameter sarkopenia pada usila. Desain penelitian intervensi dilakukan pada usila di komunitas Kota Bandung, Jawa Barat periode bulan Mei sampai Juli 2016. Sebanyak 30 partisipan (usia 60-81 tahun) diukur massa otot menggunakan bioelectrical impedance analysis (BIA) dan kekuatan otot menggunakan dinamometer tangan, serta uji jalan 6 menit untuk mengukur performa fisik. Perbedaan bermakna ditemukan pada kekuatan otot tangan $(\mathrm{p}=0,007)$ dan jarak tempuh jalan $(\mathrm{p}=0,000)$ setelah dilakukan latihan kekuatan dengan pita elastik, tetapi tidak didapatkan perbedaan bermakna pada massa otot tangan dan kaki $(\mathrm{p}=0,236)$ walaupun terjadi peningkatan massa otot setelah dilakukan latihan selama 12 minggu. Simpulan, penambahan latihan kekuatan dengan pita elastik pada program senam usila meningkatkan secara bermakna kekuatan otot dan performa fisik usila.
\end{abstract}

Kata kunci: Latihan kekuatan, pita elastik, usila 


\section{Introduction}

The elderly population is continuing to increase rapidly in the world, including in Indonesia. Older people in Indonesia increased to more than $7 \%$ of the population in 2012 along with an increase in live expectancy from 64.5 years old in 2000 (7.18\%) to 69.65 years old in 2011 (7.58\%). ${ }^{1}$

Studies have shown that the aging process is related to age-related progressive loss syndrome of the muscle mass and the resulting loss of strength and function, known as sarcopenia. This condition combines with the physiological process of elderly that are generally less physically active than younger adults, will reduce quality and expectancy of life in older people. ${ }^{2,3}$

Prevention and treatment of sarcopenia are something that should be done to achieve successful aging, that includes keeping the ability of the elderly to live independently to perform their daily functional tasks. ${ }^{4}$ Therefore, it is essential to develop an effective program to support the elderly in increasing their physical activity and habitual physical activity behaviors. ${ }^{3}$

In Indonesia, some exercises developed for the elderly. In general, the component of the exercise consists of flexibility, balance, agility exercise, and less of resistance exercise (strengthening). Based on the previous studies, one of the exercise that recommended to decreased the loss of muscle strength, mass and functional capacity in elderly is resistance exercise. ${ }^{4}$

Many studies showed the resistance exercises increase strength and function in elderly. However, there is a limited study which examines the effects of using an elastic band (EB) as a tool in resistance training. ${ }^{2,5}$

Elastic band resistance training is a low-to moderate-intensity exercise that is simple to use, portable, economical (inexpensive) and has safety advantages for older people. It provides variable resistance and allows changes in the external load over a range of motions. When an elastic material stretched, the amount of resistance in the material is proportional to deformation its initial length. Using EB will decrease the risk of excessive weight loading that may cause the elderly injured..$^{2,5}$

The purpose of this study was to understand the effect of EB resistance exercise on parameters of sarcopenia (muscle mass, muscle strength, and physical performance) in elderly community- dwelling.

\section{Methods}

This interventional study conducted using preposttest observation in community-dwelling elderly in Bandung, West Java, from May until July 2016. The inclusion criteria for the subject of this study were age more than 60 years old, able to walk independently without an assistive device, cooperative, and routinely doing exercise. They excluded if their score of mini-mental state examination were less than 17 , having a history of unstable cardiorespiratory problems, diabetes mellitus, using an artificial implant, in hormonal therapy and using long term steroid. Subjects will be excluded from the study if they absent in elastic band exercises twice in a row or three times non-consecutively. All participants have to complete resistance exercise using elastic band (ÒThera-Band), three times per week in 12 consecutive weeks. Exercise initiated by choosing the appropriate EB (yellow, green, or red) for each participant (based on 10 RM maximal in doing biceps curl for each color). Exercise in EB consisted of reverse flies, chest press, side shoulder raise, deadlift, upright row, biceps curl, triceps extension, leg press, hip flexion, and knee extension. Evaluation of maximal intensity was done every four weeks until 12 weeks.

Muscle mass measured using portable bioelectrical impedance (BIA, ÒTanita BC 601, Tokyo, Japan). A hand dynamometer (ÒJamar, Lafayette, USA) used to measure the muscle strength while physical performance measured through a 6-minute walking test to measure the walking distance. Characteristics of the subjects that may interfere with the result, such as age, body mass index (BMI), and level of activity (using the Global Physical Activity Questionnaire score) recorded.

Chi-square test was used to analyze the characteristics of the subjects. The ShapiroWilk test determines the data normality test. The difference between pre and post-exercise analyzed using $t$ test if the data distribution is normal and Wilcoxon match pair if data were not in the normal distribution.

The protocol of this study approved by the Health Research Ethics Committee, Faculty of Medicine, Universitas Padjadjaran Bandung with letter number: 115/UN6.C1.3.2/KEPK/PN/2016. 


\section{Results}

In this study, the writer able to collect exercise data from 25 elderly females and five male. Seven subjects dropped out because they could not complete the required resistance exercises. Characteristics of the subjects are in Table 1.

Most of the subjects of this study have an overweight body mass index and more significant muscle strength and mass on right hand and leg. Most of the subjects (60\%) have GPAQ score in high activity level classification, and other (40\%) have moderate level physical activity. In this study, we did not differentiate dominant or nondominant hand; it meant both right and left leg mass and strength recorded as a single variable that analyzed in the next step.

Table 2 shows the increasing average of muscle mass after the exercise both in arm and leg, meanwhile the Table 3 shows the significant increasing average after exercise only happened on muscle strength and walking distance, but not in muscle mass.

\section{Discussion}

Aging changes all body part, including the musculoskeletal system. This changing in skeletal muscle is characterized by loss of muscle mass and reduce muscle function due to loss of motor units, changes in muscle fiber type, muscle fiber atrophy, and reduced neuromuscular activation. These process caused adverse effects, such as delayed reaction time, decreasing of strength, movement velocity, and muscle forces identified as primary factors of disability (decrease of functional capability) and loss of independence in older people. ${ }^{6}$

The changes also accompanied by alteration of muscle metabolism, including insulin sensitivity and mitochondrial capacity. It also diminished regenerative capacity and satellite cell potential, neuromuscular junction (NMJ) dysfunction and vascular changes that likely further compromise the muscle function. ${ }^{7}$ All of these changes may further reinforcing sedentary habits that made the vicious cycle, which in turn promote further weakness and loss of power causing further functional disability. ${ }^{8}$

The findings of the study above showed that physical inactivity is a secondary factor affecting muscle aging. Exercise or physical activity is well-established countermeasures against that condition as a secondary aging (aging that involving interactions of primary aging with environmental influences and disease). ${ }^{9}$

Resistance training, as one type of physical exercise, is probably the most effective therapy and will provoke beneficial adaptation to the muscle. ${ }^{2,10}$ Resistance exercise acutely increases muscle protein synthesis, prevent age-associated intermuscular adipose tissue infiltration, improve the neural and vascular function of older subjects. It also promotes specific type II muscle fiber hypertrophy and also improves strength and physical performance by blocking muscle degradation pathways via follistatin rather than inducing muscle growth through the IGF1 pathway. ${ }^{11,12}$ Muscle accretion from resistance exercise may be regulated by an increase in the activation of the mTOR muscle protein synthetic pathway, satellite cell activation and proliferation, anabolic hormone production and a decrease in catabolic cytokine activity. ${ }^{13}$

Evidence suggested that resistance training with EB increases functional performance and improves muscle mass in older people. This kind of exercise, effective in reversing age-related changes and enhancing the quality of life among older people. ${ }^{14}$ Elastic band resistance training can help elderly gain strength in a similar way to that of using free weights or a weight training machine. Resistance exercise using EB can be used to perform an extensive range motion and initiate eccentric and concentric muscle contractions and also allows users to exercise by adjusting grip width or rubber stiffness to achieve a greater or lesser intensity. ${ }^{14}$

By doing EB resistance exercise, elderly partially against sarcopenia that has the inflammatory process as one of the underlying cause by lowering the level of TGF-Ò and improving the immune system. ${ }^{15}$ The other mechanisms proposed is the result of the study that showed the positive impact of the exercise to mitochondria, an organelle that thought to be impaired along in increasing of age. Exercise training, including endurance and resistance exercise, stimulates mitochondria biogenesis through increases in the peroxisome proliferatoractivated receptor coactivator 1a (PGC-1a). ${ }^{16}$ Recent studies also suggested that exercise can improve function/efficiency of mitochondria through the remodeling of the mitochondrial 
Table 1 Characteristics of Subjects

\begin{tabular}{lccc}
\hline Variables & Mean (SD) & Median & $\begin{array}{c}\text { Range } \\
\text { (Min.-Max.) }\end{array}$ \\
\hline Age (years) & $69.73(5.95)$ & 69.50 & $60.00-81.00^{*}$ \\
Height $(\mathrm{cm})$ & $15340(7.11)$ & 152.00 & $141.00-165.00^{*}$ \\
Weight $(\mathrm{kg})$ & $58.80(5.92)$ & 59.50 & $44.00-75.00^{*}$ \\
BMI $\left(\mathrm{kg} / \mathrm{m}^{2}\right)$ & $25.27(2.68)$ & 25.40 & $19.50-29.20$ \\
Right hand muscle strength $(\mathrm{kg})$ & $17.96(5.05)$ & 18.17 & $8.00-30.00^{*}$ \\
Left hand muscle strength $(\mathrm{kg})$ & $16.31(3.91)$ & 16.67 & $9.33-26.67^{*}$ \\
Right hand muscle mass $\left(\mathrm{kg} / \mathrm{m}^{2}\right)$ & $1.68(0.28)$ & 1.60 & $1.30-2.50$ \\
Left hand muscle mass $\left(\mathrm{kg} / \mathrm{m}^{2}\right)$ & $1.56(0.25)$ & 1.50 & $1.30-2.30$ \\
Right leg muscle mass $\left(\mathrm{kg} / \mathrm{m}^{2}\right)$ & $6.72(0.98)$ & 6.60 & $5.60-9.70$ \\
Left leg muscle mass $\left(\mathrm{kg} / \mathrm{m}^{2}\right)$ & $6.62(0.93)$ & 6.45 & $5.50-9.10$ \\
Walking distance $(\mathrm{m})$ & $365.63(31.83)$ & 375.00 & $315.00-435.00$ \\
\hline
\end{tabular}

BMI: body mass index; *Normal data distribution

Table 2 Muscle Strength and Mass Before and After Elastic Band Exercise

\begin{tabular}{lccc}
\hline Variables & Mean (SD) & Median & $\begin{array}{c}\text { Range } \\
\text { (Min.-Max.) }\end{array}$ \\
\hline Muscle strength (kg) & $34.25(8.48)$ & 35.50 & $18.33-56.67$ \\
$\quad$ Before exercise & $36.99(10.03)$ & 36.83 & $19.67-60.67$ \\
$\quad$ After exercise & & & \\
Muscle mass $\left(\mathrm{kg} / \mathrm{m}^{2}\right)$ & $16.59(2.38)$ & 16.15 & $13.80-23.10$ \\
$\quad$ Before exercise & $16.93(2.54)$ & 16.35 & $14.40-24.60$ \\
$\quad$ After exercise & &
\end{tabular}

Table 3 Comparison of Muscle Strength, Muscle Mass and Walking Distance Before and After Elastic Band Exercise

\begin{tabular}{lccc}
\hline Variables & Before Exercise & After Exercise & p Value \\
\hline Muscle strength $(\mathrm{kg})$ & 34.25 & 36.99 & $0.0066^{*}$ \\
Muscle mass $\left(\mathrm{kg} / \mathrm{m}^{2}\right)$ & 16.15 & 16.35 & 0.2400 \\
Walking distance $(\mathrm{m})$ & 365.60 & 402.50 & $0.0000^{*}$ \\
\hline${ }^{*}$ Significance if $\mathrm{p}<0.05$ & &
\end{tabular}

${ }^{*}$ Significance if $\mathrm{p}<0.05$

network (fusion, fission, and autophagy). ${ }^{17}$ Exercise also will induce NMJ hypertrophy that aging process limits the capacity of NMJ to adapt to endurance training. ${ }^{3,7}$ Physical activity also has been shown to affect the regenerative capacity of older muscles positively. Both resistance and endurance exercise training ranging from few weeks to months have shown to increase the number of satellite cells, that critical for regeneration, in old animals and subjects. ${ }^{18}$

The results of this study support previous works that showed that 16 weeks of Tai-Chi and resistance training using Thera-band improved muscle strength of upper and lower extremities, lower body flexibility, aerobic endurance, and agility/dynamic balance. ${ }^{19}$ The previous study 
also showed that elastic resistance therapy for 12 weeks exerted a significant beneficial effect on muscle mass, muscle quality, and physical function in older women with sarcopenic obesity. Other study showed that with only six weeks of stretching or resistive training, it could improve the functional status of older people. ${ }^{20}$

However, this study did not make any significant difference in muscle mass after doing EB exercise, even though there is an increase in muscle mass. That difference results of this study compared to previous works may be influenced by the characteristics of subjects. Gender, age, body mass, physical activity, history of nutrition of the participant and also exercise prescription protocol, including the volume of training that has been given to the subject, may influence the result.

These study participants mostly are more than 65-year-old; it may cause the effectiveness of exercise prescription should be evaluated. The study showed that the muscle power of the elderly with age over 60 decrease rapidly at a rate of $3 \%$ to $5 \%$ annually. This rapid decreasing of power is affecting the ability to move and react quickly. Therefore, effective strengthening practices must be employed and adjusted to maintain the highest level of function and achieve optimal aging for different age. ${ }^{8}$

This study showed that women have biological superior but suffer higher levels of morbidity compare to men. Beyond 65 years old, the rate of aging showed a rapidly increasing. The women have relatively lower functional capabilities, but a slower rate of aging compare to men. Besides gender, age also influenced the curvilinear relationship of body mass index with body fat percentage (\%BF). The study found out that elderly subjects reduce BMI and increase $\mathrm{BF} \%$ at the same time. The mean difference in BF\% between males and females also increased with age, where females gained more fat than males when they became old. ${ }^{21}$

The difference result of this study to previous works could be from the sample of the study, where the number of females is more than males. Also, the subject of this study mostly overweight. This condition should be noted since sarcopenia and obesity are co-morbid illnesses which can cause functional and metabolic impairments in the elderly. Older patients with sarcopenic obesity had two-timed higher risk of developing daily living disability than those without sarcopenic obesity. ${ }^{22}$

Lower mitochondrial capacity and efficiency is associated with reduced physical performance in the elderly. ${ }^{23}$ The elderly with high function have been shown to maintain muscle mass and mitochondrial capacity, whereas low-functioning elderly individuals show decreased muscle mass and mitochondrial function compared to young individuals. ${ }^{24}$ The study supports the finding of the previous works that showed EB exercise that only makes a significant increase in muscle strength and physical performance. Most of the subjects in this study have a high classification of physical activity when entering the study. As in one study said that muscle mass did not show a significant association with physical performance in weak elderly, but the significant and high association showed between muscle strength and physical performance in weak elderly. ${ }^{25} \mathrm{~A}$ study that only done in Bandung area, generalized exercise, and the majority of highlevel physical activity in the subject, cause the results of this study are limited to be generalized. Another study should be done with the various elderly population, with customized intensity in long term study to make a more appropriate exercise that meets the need of general elderly in Indonesia population. To make prevention of sarcopenia risk development, the body fat beside BMI should become one of further study variable considering its role in inflammation and physical performance of the elderly. Body mass index often criticized for not distinguishing solid fat form lean mass and ignoring fat distribution, which may limit its ability to reveal actual health effects. Other factors such as lifestyle factors in example nutritional status (including decline in appetite and food in aging, less physical activity and psychosocial factors), should also be studied in the relation of the effectiveness of the exercise. ${ }^{6}$

To make an appropriate and effective regimen of EB exercise, nutrition, including the intervention, should be considered. There is evidence suggesting that nutrition intervention (essential amino acids, milk-based proteins, creatine monohydrate, essential fatty acids, and vitamin D), when consumed in conjunction with resistance exercise, may further augment the increase in muscle mass and strength. ${ }^{13}$ This nutrition has anti-inflammatory or anti-catabolic properties, which could accelerate muscle recovery following exercise. The co-ingestion of creatine and whey protein during resistance 
exercise may augment muscle hypertrophy, with even more significant gains observed when conjugated linoleic acid (CLA) included. ${ }^{13}$

The volume of training and age of participation are an essential determinant of exercise effectiveness, suggesting that higher dosages result in greater adaptive-response, and those aging individuals should consider starting a regimen of resistance exercise as early as possible, to optimize the results. ${ }^{12}$

Result of EB resistance exercise in this study supports the use of this exercise in community health promotion or care centers as an addition to the frequent elderly exercise for improving muscle strength and functional performance and to prevent sarcopenia.

\section{Conclusion}

Elastic band strengthening exercise can increase muscle strength and physical performance but do not significantly increase the muscle mass in the elderly.

\section{Conflict of Interest}

There is no conflict of interest in this study.

\section{References}

1. Pusat Data dan Informasi, Kementerian Kesehatan Republik Indonesia. Gambaran kesehatan lanjut usia di Indonesia. Buletin Jendela Data dan Informasi Kesehatan [Internet]. 2011 [cited 2019 July 17];Semester I:1-18. Available from: http://www.pusdatin. kemkes.go.id/resources/download/ pusdatin/buletin/buletin-lansia.pdf.

2. Karaganova I. Resistance training with thera-band to reduce effects of sarcopenia in older people. In: Smrikarov A, Antonova D, Stoyanov K, Stoyanov S, Iliev T, Ivanov V, et al., editors. Proceedings of the University of Ruse "Angel Kanchev" Volume 54 Book 8.1: health prevention and social activities. Ruse, Bulgaria: University of Ruse "Angel Kanchev"; 2015 [cited 2019 July 17]. p. 13340. Available from: http://conf.uni-ruse.bg/ bg/docs/cp15/8.1/8.1-26.pdf.

3. Taylor D. Physical activity is medicine for older adult. Postgrad Med J. 2014;90(1059):2632.

4. Peterson MD, Gordon PM. Resistance exercise for the aging adult: clinical implications and prescription guidelines. Am J Med. 2011;124(3):194-8.

5. Yu W, An C, Kang H. Effects of resistance exercise using thera-band on balance of elderly adults: a randomized controlled trial. J Phys Ther Sci. 2013;25(11):1471-3.

6. Tieland M, Trouwborst I, Clark BC. Skeletal muscle performance and ageing. J Cachexia Sarcopenia Muscle. 2018;9(1):3-19.

7. Gonzalez-Freire M, de Cabo R, Studenski SA, Ferrucci L. The neuromuscular junction: aging at the crossroad between nerves and muscle. Front Aging Neurosci. 2014;6:208.

8. Avers D, Brown M. White paper: strength training for the older adult. J Geriatr Phys Ther. 2009;32(4):148-52.

9. Booth FW, Laye MJ, Roberts MD. Lifetime sedentary living accelerates some aspects of secondary aging. J Appl Physiol. 2011;111(5):1497-504.

10. Schober-Halper B, Hofmann M, Oesen S, Franzke B, Wolf T, Strasser EM, et al. Elastic band resistance training influences transforming growth factor- $\beta$ receptor I mRNA expression in peripheral mononuclear cells of institutionalised older adults: the Vienna Active Ageing Study (VAAS). Immun Ageing. 2016;13:22.

11. Hofmann M, Schober-Halper B, Oesen S, Franzke B, Tschan H, Bachl N, et al. Effects of elasticbandresistancetraining and nutritional supplementation on muscle quality and circulating muscle growth and degradation factors of institutionalized elderly women: the Vienna Active Ageing Study (VAAS). Eur J Appl Physiol. 2016;116(5):885-97.

12. Peterson MD, Sen A, Gordon PM. Influence of resistance exercise on lean body mass in aging adults: a meta-analysis. Med Sci Sports Exerc. 2011;43(2):249-58.

13. Candow DG, Forbes SC, Little JP, Cornish SM, Pinkoski C, Chilibeck PD. Effect of nutritional interventions and resistance exercise on aging muscle mass and strength. Biogerontology. 2012;13(4):345-58.

14. Melchiorri G, Rainoldi A. Muscle fatigue induced by two different resistances: elastic tubing versus weight machines. J Electromyogr Kinesiol. 2011;21(6):954-9.

15. Rajabi P, Isanejad A, Samadi A, Amini H. The effect of resistance training with theraband on the transforming growth factor- $\beta$ in 
the elderly women. Immunoregulation. 2018;1(2):81-6.

16. Geng T, Li P, Okutsu M, Yin X, Kwek J, Zhang $\mathrm{M}$, et al. PGC-1 1 plays a functional role in exercise-induced mitochondrial biogenesis and angiogenesis but not fiber-type transformation in mouse skeletal muscle. Am J Physiol Cell Physiol. 2010;298(3):C572-9.

17. Smuder AJ, Kavazis AN, Min K, Powers SK. Exercise protects against doxorubicininduced oxidative stress and proteolysis in skeletal muscle. J Appl Physiol. 2011;110(4):935-42.

18. Joanisse S, Nederveen JP, Baker JM, Snijders T, Iacono C, Parise G. Exercise conditioning in old mice improves skeletal muscle regeneration. FASEB J. 2016;30(9):325668.

19. Lin SF, Sung HC, Li TL, Hsieh TC, Lan HC, Perng SJ, et al. The effects of Tai-Chi in conjunction with thera-band resistance exercise on functional fitness and muscle strength among community-based older people. J Clin Nurs. 2015;24(9-10):1357-66.

20. Locks RR, Costa TC, Koppe S, Yamaguti AM, Garcia MC, Gomes ARS. Effects of strength and flexibility training on functional performance of healthy older people. Rev Braz Fisioter. 2012;16(3):184-90.

21. Ranasinghe C, Gamage P, Katulanda P,
Andraweera N, Thilakarathne S, Tharanga P. Relationship between body mass index (BMI) and body fat percentage, estimated by bioelectrical impedance, in a group of Sri Lankan adults: a cross sectional study. BMC Public Health. 2013;13:797.

22. Bell JA, Carslake D, O’Keeffe LM, Frysz M, Howe LD, Hamer M, etal. Associations of body mass and fat indexes with cardiometabolic traits. J Am Coll Cardiol. 2018;72(24):314254.

23. Coen PM, Jubrias SA, Distefano G, Amati F, Mackey DC, Glynn NW, et al. Skeletal muscle mitochondrial energetics are associated with maximal aerobic capacity and walking speed in elderly. J Gerontol A Biol Sci Med Sci. 2013;68(4):447-55.

24. Joseph AM, Adhihetty PJ, Buford TW, Wohlgemuth SE, Lees HA, Nguyen LMD, et al. The impact of aging on mitochondrial function and biogenesis pathways in skeletal muscle of sedentary high- and lowfunctioning elderly individuals. Aging Cell. 2012;11(5):801-9.

25. Kim KE, Jang SN, Lim S, Park YJ, Paik NJ, Kim KW, et al. Relationship between muscle mass and physical performance: is it the same in elderly with weak muscle strength? Age Ageing. 2012;41(6):799-803. 